\title{
Clinical Utility of Endoscopic Ultrasound-Guided Fine-Needle Aspiration Biopsy In Mixed Ductal-Neuroendocrine Neoplasms of The Pancreas
}

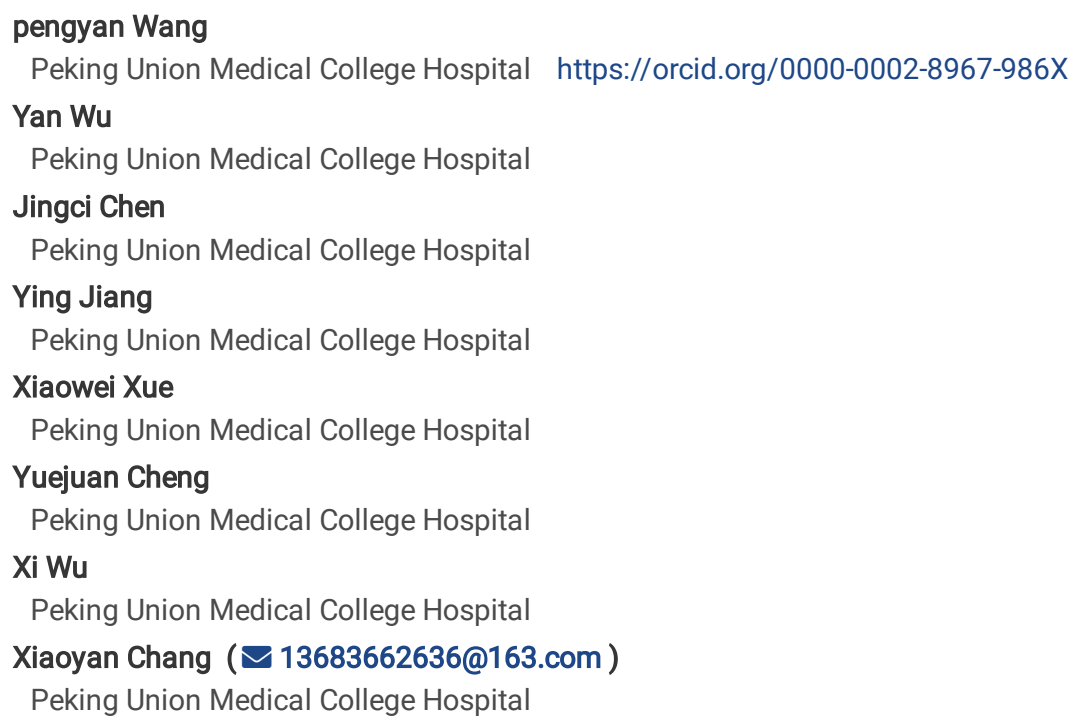

Research

Keywords: pancreas, mixed ductal-neuroendocrine neoplasms, EUS-FNA, prognosis

Posted Date: February 11th, 2021

DOI: https://doi.org/10.21203/rs.3.rs-207925/v1

License: (c) (i) This work is licensed under a Creative Commons Attribution 4.0 International License. Read Full License 


\section{Abstract}

Background: Endoscopic ultrasound-guided fine needle aspiration (EUS-FNA) biopsy is the first line diagnostic tool used in the evaluation of solid pancreatic masses with high sensitivity and specificity prior to the surgery. Mixed ductal-neuroendocrine neoplasms of the pancreas are rare entity consisting of both ductal adenocarcinoma and neuroendocrine neoplasms, with each component representing at least $30 \%$.

Methods: We performed a retrospective analysis of patients with a diagnosis of pancreatic mixed ductal adenocarcinoma and neuroendocrine neoplasms by EUS-FNA specimens at Peking Union Medical College Hospital between 2010-2019 and presented a review of the literature.

Results: A total of 3 cases ( 1 male and 2 females) were evaluated, aged 46,38 and 62 years, and presented with 3-cm, 2.3-cm and 1.8-cm pancreatic masses, respectively. All the patients presented with abdominal pain and underwent EUS-FNA biopsy. FNA smears revealed a mixture of ductal adenocarcinoma and neuroendocrine neoplasms, identified by immunohistochemistry. According to Ki-67 proliferation index and mitotic count, the tumor grades of the neuroendocrine component were classified as NET G2 in 2 cases (cases 2 and 3) and NEC in 1 (case 1). All of the patients received adjuvant therapy. The diagnosis of patient 1 was confirmed on surgical excision, and she died 5 months after surgery due to hepatic metastases. The other two patients did not undergo surgery, but achieved long - term survival of 3 and 5 years, respectively. To date, 34 cases of pancreatic mixed ductal adenocarcinoma and neuroendocrine neoplasms have been reported in the English language literature including our present three cases. Among them, 5 of 12 patients who underwent preoperative biopsy were diagnosed as combined ductal adenocarcinoma and neuroendocrine neoplasms, of which 3 surgical resection specimens available were identified as mixed ductal-neuroendocrine neoplasms.

Conclusion: We suggest that EUS-FNA biopsy is the most effective method for rapid evaluation of pancreatic mixed ductal-neuroendocrine neoplasms with high sensitivity, which is important to determine the most optimum therapy. If the tumor grades of the neuroendocrine component were classified as NET G2 by EUS-FNA biopsy, we propose appropriate adjuvant therapy rather than surgery.

\section{Background}

Mixed tumors exhibiting both exocrine and neuroendocrine features can originate in all organs. The mixed adeno-neuroendocrine carcinoma (MANEC) was first introduced in the World Health Organization (WHO) 2010 classification of digestive system and has been renamed as mixed neuroendocrine non-neuroendocrine neoplasms (MiNENs) in the WHO 2017 classification of pancreatic neuroendocrine neoplasms (NENs) [1]. MiNENs are composite neoplasms containing both neuroendocrine and non-neuroendocrine component, each comprising at least $30 \%$ of the tumor volume [1, 2].

The pancreas is an organ composed of endocrine and exocrine (acinar and ductal) components [3]. Pancreatic MiNENs are extremely rare, which comprise $0.2 \%$ of all pancreatic neoplasms and $3.0 \%$ of pancreatic NENs [4]. The most common subtype is mixed acinar-neuroendocrine carcinoma [5]. To our knowledge, only 31 cases of pancreatic mixed ductal-neuroendocrine neoplasms have been published in the English literature [3, 6-33]. The cases were mostly identified by surgical specimens, with 3 of them detected incidentally during autopsy $[10,13,17]$. Furthermore, twelve cases were performed by preoperative biopsy, only 2 cases were accurately diagnosed both ductal and neuroendocrine components [21, 33].

Endoscopic ultrasound guided fine needle aspiration (EUS-FNA) biopsy has been widely used and become the most effective technique for preoperative evaluation of pancreatic tumors. However, the use of EUS-FNA to help the diagnosis of pancreatic MiNENs is limited, since such condition is extremely unusual $[5,34]$. The rarity of these neoplasms and the limitation of biopsy samples are obstacles to diagnosis and treatment. As the treatment depends on morphological diagnosis, cytological and biopsy analysis via EUS-FNA are particularly important [29, 35-37]. Here, we report three cases of pancreatic mixed ductal adenocarcinoma and neuroendocrine neoplasms diagnosed by preoperative EUS-FNA biopsy, one of which was verified as mixed ductal-neuroendocrine carcinoma by operation. We also presented a literature review and focused on the correlation between preoperative cytology and subsequent surgical pathology.

\section{Methods}

The pathology records over a 10-year period (2010-2019) were retrieved from the archive files of the Department of Pathology, Peking Union Medical College Hospital. Three patients with mixed pancreatic ductal adenocarcinoma and neuroendocrine neoplasms diagnosed by preoperative EUS-FNA were selected. Hematoxylin and eosin (H\&E) slides and immunohistochemistry (IHC) results were reviewed by two expert pathologists. The clinical and follow-up data were collected from the medical records or telephone inquiry. Patient data was analyzed to the last follow-up before February 15 , 2020. Patients were enrolled after providing oral consent, and this study was approved by the Institutional Review Board of Peking Union Medical College Hospital.

All EUS-FNAs were performed using 22-gauge needles (Echotip, Wilson-Cook, and Winston-Salem, NC). The aspirated material was smeared onto 610 glass slides and immediately fixed in 95\% ethanol for Hematoxylin and eosin (H\&E) staining. Additionally, the subsequent materials from cases 1 and 2 were formalin-fixed and paraffin-embedded for cell blocks. Patient 1 underwent surgical resection after 6 cycles of neoadjuvant chemotherapy. The specimens of the surgery were fixed in $10 \%$ neutral formalin and processed by routine histology techniques. 
The immunohistochemical analysis was performed on paraffin-embedded sections on a DAKO Autostainer. The primary antibodies used were synaptophysin (SP11, dilution 1:100; Thermo), chromogranin A (DAK-A3, dilution 1:100; DAKO), CD56 (123C3, dilution 1:100; DAKO), CK7 (OVTL12/30, dilution 1:400; DAKO), CK19 (RCK108, dilution 1:100, DAKO), cytokeratin (AE1/AE3, dilution 1:100; DAKO), and Ki-67 (MIB-1, dilution 1:200; DAKO).

\section{Results}

\section{Clinicopathological Features}

The clinical and pathological data of the 3 cases are summarized in Table 1.1 male and 2 females were evaluated, aged 46,38 and 62 years, respectively. All of the patients presented with abdominal pain at admission. Ultrasonography of the abdomen, contrast-enhanced computed tomography (CT) and magnetic resonance imaging (MRI) showed the pancreatic solid mass in the head in 2 cases and in the body in 1 , with a diameter of 2.3-cm, 2.5-cm and 3-cm, respectively (Fig. 1). The image also demonstrated the presence of multiple hepatic metastases in $2 \mathrm{cases}$ (cases 1 and 2) and extensive vascular vascular invasion in 1 (case 3).

Table 1

Summarizing clinicopathological features of the 3 cases

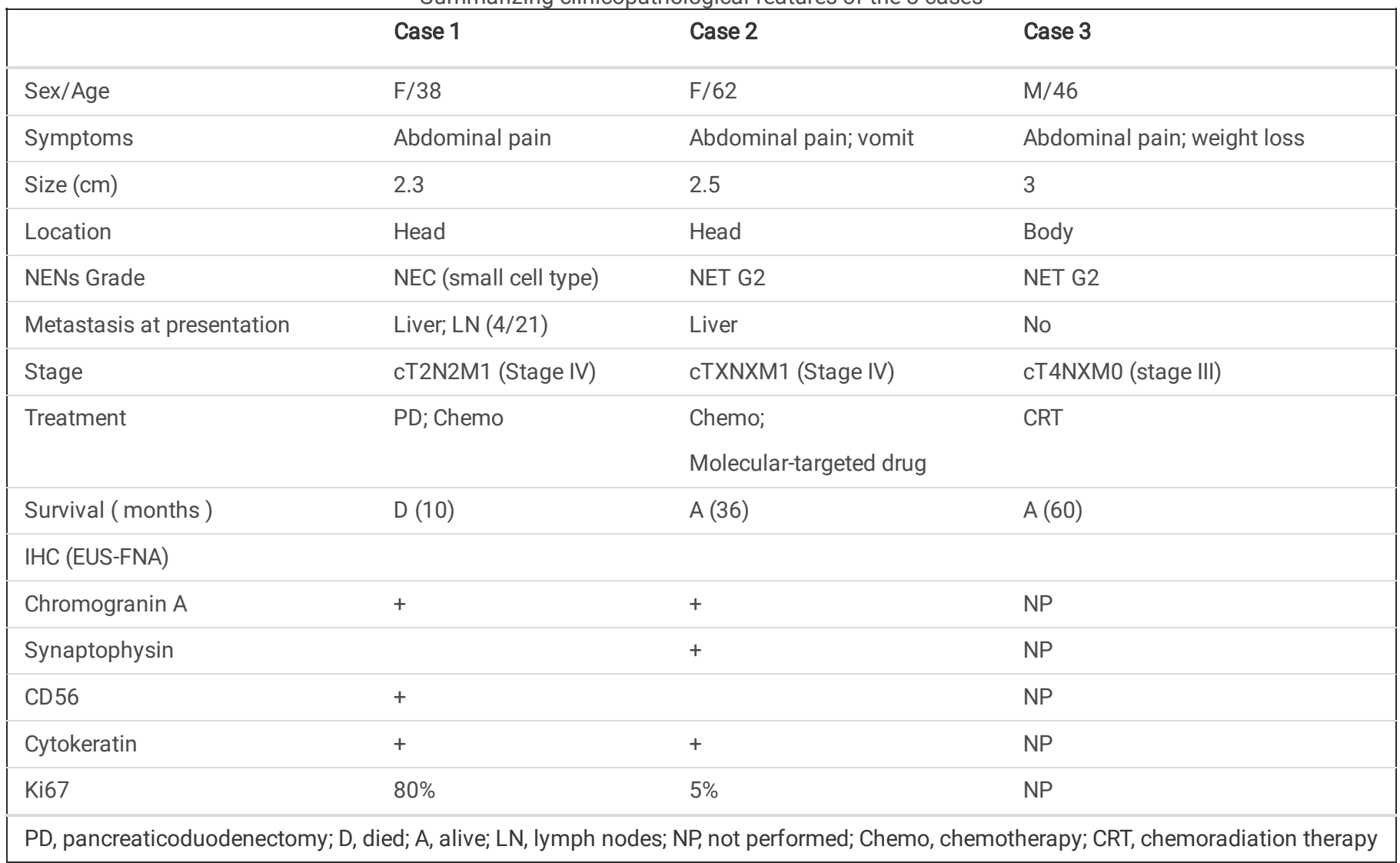

All of the three patients underwent preoperative EUS-FNA. Pancreas FNA cytology revealed that the tumor consisted of two components in the hemorrhagic / fibroblastic stromal background: (1) A predominant endocrine component showed dispersed single plasmacytoid cells with eosinophilic and eccentrically located cytoplasm, and clusters with round to oval nuclei, prominent nuclear molding, 'salt-and-pepper' chromatin, and moderate finely granular cytoplasm. Immunohistochemistry staining revealed diffuse positivity for synaptophysin and chromogranin A. Focal weak cytokeratin positivity was seen. (2) A minor adenocarcinoma component showed abortive glandular structures of cells with round to oval nuclei, coarse chromatin, prominent nucleoli, and relatively rich cytoplasm with scant intracytoplasmic mucin, which were immunohistochemically positive for cytokeratin but negative for endocrine markers (Figure. 2-3). Based on these findings, the diagnosis of primary mixed ductal adenocarcinoma and neuroendocrine neoplasms of the pancreas was made. Furthermore, the neuroendocrine component of the 3 patients was classified as NEC (case 1) and NET G2 (cases 2 and 3), respectively, according to the mitotic rate and Ki-67 labeling index.

The clinical features were shown in Table 1. All of the three patients were not candidates for surgery, so they received systemic treatment targeting the neuroendocrine component. Patient 2 received chemotherapy with octreotide acetate and molecular - targeted drug (everolimus) with inhibitory effect on tumor growth and had no sign of disease progression 3 years later after diagnosis. Patient 3 received chemotherapy treatment with gemcitabine hydrochloride $(1000 \mathrm{mg} / \mathrm{m} 2)$ and tegafur (60mg D1-D14) followed by local radiation and was still alive with no disease progression 5 years later at the last follow-up. 
After six cycles of chemotherapy using VP-16 (140mg D1-D3) and cisplatin (40mg D1, 30mg D2-D3), the patient of case 1 underwent pancreatoduodenectomy with regional lymph node dissection and partial hepatectomy. Grossly, the pancreas revealed an ill-defined, hard and grey mass within the head invading duodenal wall. Microscopically, the tumor showed a moderate differentiated adenocarcinoma and a poorly differentiated neuroendocrine carcinoma (NEC) intermingling together (Fig. 4a). The adenocarcinoma exhibited tubular growth pattern with positive expression of epithelial markers (cytokeratin, CK7 and CK19), while negative expression of neuroendocrine markers (synaptophysin and chromogranin A). The NEC cells were arranged in irregular sheets with amphophilic cytoplasm, prominent nucleoli and a high mitotic rate (30/10 HPFs). Comedo-like necrosis and geographic necrosis were seen in NEC component. The "organoid" structure and pseudorosette pattern was rarely seen. NEC component occupied approximately $60 \%$ of the lesion, which immunoreactive to synaptophysin, chromogranin A (Fig. $4 \mathrm{~b}$ ) and partly immunoreactive to cytokeratin but negative to CK7 or CK19. Ki-67 index was about $85 \%$. Four of 24 dissected regional lymph nodes and the liver were involved. The liver and 2 involved lymph nodes were positive for metastatic neuroendocrine carcinoma only (Fig. $4 \mathrm{c}$ ). The other 2 lymph nodes were infiltrated by a mixture of adenocarcinoma and neuroendocrine carcinoma (Fig. $4 \mathrm{~d}$ ). The patient received six cycles of adjuvant gemcitabine hydrochloride (1200mg D1-D8) and cisplatin (40mg D1-D8) therapy and died due to diffuse hepatic metastases 5 months after operation.

\section{Total analysis of thirty-four cases reported in the literature (including our present three)}

Thirty-four cases of mixed ductal neuroendocrine neoplasms of the pancreas have been identified, including three cases reported herein (Table 2). There was a male predominance $(21 / 34,61.8 \%$ ) and patient age ranged from 21 to 76 years (median age 63 years). The tumors were mostly located in the head of the pancreas (18/33, $54.5 \%$ ), with a mean size of $4.1 \mathrm{~cm}$ in greatest dimension (range, $1.0-19.0 \mathrm{~cm}$ ). The most common symptom was abdominal pain $(13 / 33,39.4 \%)$ and jaundice $(13 / 33,39.4 \%)$, followed by weight loss $(8 / 33,24.2 \%)$. Most of tumors were non-functional (26/33, $78.8 \%$ ) according to the symptoms and blood test results. Preoperative cytological or biopsy examination of ERCP (Endoscopic retrograde cholangiopancreatography)/EUS-FNA was performed in 12 patients, among which 5 exhibited mixed morphologic features, 6 with a pure adenocarcinoma appearance, and 1 with a pure neuroendocrine appearance. Ten surgical resection specimens available showed $30 \%$ (3/10) correlation between preoperative cytology/histology and postoperative pathology. Furthermore, a review of ERCP/EUS-FNA smear of cases 26 and 29 showed a mixture of the two components. 
Table 2

Reported cases of pancreatic mixed ductal - endocrine neoplasms

\begin{tabular}{|c|c|c|c|c|c|c|c|c|c|}
\hline Patient & Reference & $\begin{array}{l}\text { Age/ } \\
\text { Sex }\end{array}$ & Symptoms & Location & $\begin{array}{l}\text { Tumor } \\
\text { Size } \\
\text { (cm) }\end{array}$ & Metastasis & $\begin{array}{l}\text { Preoperative } \\
\text { Diagnosis }\end{array}$ & Treatment & $\begin{array}{l}\text { Postoperative } \\
\text { Course } \\
\text { (months) }\end{array}$ \\
\hline 1 & $\begin{array}{l}\text { Eusebi et al, } \\
1981\end{array}$ & $65 / M$ & Jaundice & Head & 6 & liver & NA & Surgery & D (2 days) \\
\hline 2 & $\begin{array}{l}\text { Reid et al, } \\
1982\end{array}$ & $50 / \mathrm{M}$ & $\begin{array}{l}\text { Abdominal } \\
\text { pain, weight } \\
\text { loss }\end{array}$ & Head & NA & LN & NA & $\begin{array}{l}\text { DP } \\
\text { CRT }\end{array}$ & A (8) \\
\hline 3 & $\begin{array}{l}\text { Reid et al, } \\
1982\end{array}$ & $29 / F$ & $\begin{array}{l}\text { Abdominal } \\
\text { pain, weight } \\
\text { loss, jaundice }\end{array}$ & Head & NA & No & NA & PD & A (24) \\
\hline 4 & $\begin{array}{l}\text { Schon et al, } \\
1984\end{array}$ & $62 / F$ & $\begin{array}{l}\text { Jaundice, } \\
\text { weight loss }\end{array}$ & Head & NA & LN & NA & PD & D (5) \\
\hline 5 & $\begin{array}{l}\text { Ordonez et } \\
\text { al, } 1988\end{array}$ & $62 / F$ & $\begin{array}{l}\text { Diarrhea, } \\
\text { Verner- } \\
\text { Morrison } \\
\text { syndrome }\end{array}$ & Head & 4 & Liver & $\begin{array}{l}\text { Werner-Morrison } \\
\text { syndrome }\end{array}$ & Chemo & D (13) \\
\hline 6 & $\begin{array}{l}\text { Nonomura et } \\
\text { al, } 1989\end{array}$ & $76 / \mathrm{M}$ & $\begin{array}{l}\text { Jaundice, } \\
\text { abdominal } \\
\text { fullness }\end{array}$ & Tail & 1 & No & $\begin{array}{l}\text { Hepatoma with } \\
\text { pancreatic } \\
\text { metastasis }\end{array}$ & Autopsy & $\mathrm{D}(6)$ \\
\hline 7 & $\begin{array}{l}\text { Kashiwabara } \\
\text { et al, } 1991\end{array}$ & $48 / \mathrm{M}$ & No & Head & 1.9 & No & $\begin{array}{l}\text { Pancreatic } \\
\text { endocrine tumor }\end{array}$ & PD & NA \\
\hline 8 & $\begin{array}{l}\text { Laine et al, } \\
1992\end{array}$ & $59 / \mathrm{M}$ & $\begin{array}{l}\text { Abdominal } \\
\text { pain, jaundice }\end{array}$ & Head & 6 & No & NA & PD & A (24) \\
\hline 9 & $\begin{array}{l}\text { Nonomura et } \\
\text { al, } 1992\end{array}$ & $76 / \mathrm{M}$ & $\begin{array}{l}\text { Jaundice, } \\
\text { abdominal } \\
\text { fullness }\end{array}$ & Tail & 1 & No & NA & Autopsy & $\mathrm{D}(6)$ \\
\hline 10 & $\begin{array}{l}\text { Nonomura et } \\
\text { al, } 1992\end{array}$ & $73 / F$ & $\begin{array}{l}\text { General } \\
\text { malaise }\end{array}$ & Body & 1 & No & NA & Surgery & NA \\
\hline 11 & $\begin{array}{l}\text { Hassan et al, } \\
1993\end{array}$ & $50 / \mathrm{M}$ & $\begin{array}{l}\text { Abdominal } \\
\text { pain, } \\
\text { constipation, } \\
\text { weight loss }\end{array}$ & Tail & 19 & No & NA & DP & $\mathrm{D}(10)$ \\
\hline 12 & $\begin{array}{l}\text { Okada et al, } \\
1995\end{array}$ & $21 / M$ & No & Body & 2.5 & No & NA & DP & NA \\
\hline 13 & $\begin{array}{l}\text { Morikane et } \\
\text { al, } 1997\end{array}$ & $54 / F$ & No & Body & 1 & No & $\begin{array}{l}\text { Pancreatic } \\
\text { endocrine tumor } \\
\text { or ductal } \\
\text { carcinoma }\end{array}$ & DP & A (36) \\
\hline 14 & $\begin{array}{l}\text { Terada et al, } \\
1999\end{array}$ & $62 / \mathrm{M}$ & $\begin{array}{l}\text { Zollinger- } \\
\text { Ellison } \\
\text { syndrome }\end{array}$ & Body & 10 & $\begin{array}{l}\text { Widespread } \\
\text { metastases }\end{array}$ & NA & Autopsy & D (264) \\
\hline 15 & $\begin{array}{l}\text { Leteurtre et } \\
\text { al, } 2000\end{array}$ & $74 / \mathrm{M}$ & $\begin{array}{l}\text { Jaundice, } \\
\text { weight loss }\end{array}$ & Head & 3 & LN & $\begin{array}{l}\text { Pancreatic } \\
\text { carcinoma }\end{array}$ & PD & NA \\
\hline 16 & $\begin{array}{l}\text { Tanakaya et } \\
\text { al, } 2001\end{array}$ & $72 / F$ & $\begin{array}{l}\text { Altered } \\
\text { consciousness }\end{array}$ & Body & 1.4 & No & insulinoma & Surgery & $A(72)$ \\
\hline 17 & $\begin{array}{l}\text { Chatelain et } \\
\text { al, } 2002\end{array}$ & $72 / F$ & No & Tail & 10 & No & $\begin{array}{l}\text { Pancreatic } \\
\text { endocrine tumor }\end{array}$ & DP & A (4) \\
\hline 18 & $\begin{array}{l}\text { Terada et al, } \\
2002\end{array}$ & $34 / \mathrm{M}$ & $\begin{array}{l}\text { Abdominal } \\
\text { pain }\end{array}$ & Body & 0.5 & No & $\begin{array}{l}\text { Mixed ductal- } \\
\text { endocrine } \\
\text { Carcinoma } \\
\text { (ERCP biopsy) }\end{array}$ & DP & NA \\
\hline
\end{tabular}

DP, distal pancreatectomy; PD, pancreaticoduodenectomy; Chemo, chemotherapy; CRT, chemoradiation therapy; D, died; A, alive; NA, not available; NED, no evidence of disease; LN, lymph nodes; EUS-FNA, endoscopic ultrasound guided fine needle aspiration; ERCP, endoscopic retrograde cholangiopancreatograph 


\begin{tabular}{|c|c|c|c|c|c|c|c|c|c|}
\hline Patient & Reference & $\begin{array}{l}\text { Age/ } \\
\text { Sex }\end{array}$ & Symptoms & Location & $\begin{array}{l}\text { Tumor } \\
\text { Size } \\
\text { (cm) }\end{array}$ & Metastasis & $\begin{array}{l}\text { Preoperative } \\
\text { Diagnosis }\end{array}$ & Treatment & $\begin{array}{l}\text { Postoperative } \\
\text { Course } \\
\text { (months) }\end{array}$ \\
\hline 19 & $\begin{array}{l}\text { Ballas et al, } \\
2005\end{array}$ & $65 / F$ & $\begin{array}{l}\text { Abdominal } \\
\text { pain, nausea }\end{array}$ & Tail & 12 & Spleen & $\begin{array}{l}\text { Pancreatic } \\
\text { carcinoma }\end{array}$ & $\begin{array}{l}\text { DP; } \\
\text { Splenectomy }\end{array}$ & A (18) \\
\hline 20 & $\begin{array}{l}\text { Brandi } G \text { et } \\
\text { al, } 2008\end{array}$ & $68 / M$ & $\begin{array}{l}\text { Abdominal } \\
\text { epigastric pain }\end{array}$ & Body & 1 & No & $\begin{array}{l}\text { Pancreatic } \\
\text { adenocarcinoma } \\
\text { (biopsy) }\end{array}$ & $\begin{array}{l}\text { DP } \\
\text { CRT }\end{array}$ & $\mathrm{D}(12)$ \\
\hline 21 & $\begin{array}{l}\text { Hashimoto Y } \\
\text { et al, } 2008\end{array}$ & $75 / M$ & Jaundice & Head & 3.5 & LN & $\begin{array}{l}\text { Pancreatic } \\
\text { ductal } \\
\text { adenocarcinoma } \\
\text { (ERCP cytology) }\end{array}$ & PD & $\mathrm{D}(6)$ \\
\hline 22 & $\begin{array}{l}\text { Carter et al, } \\
2008\end{array}$ & $58 / F$ & $\begin{array}{l}\text { Jaundice, } \\
\text { intractable } \\
\text { itching }\end{array}$ & Head & 2 & No & $\begin{array}{l}\text { Pancreatic } \\
\text { adenocarcinoma }\end{array}$ & PD & A (3) \\
\hline 23 & $\begin{array}{l}\text { Ahmad et al, } \\
2011\end{array}$ & $73 / M$ & $\begin{array}{l}\text { Epigastric pain } \\
\text { and weight } \\
\text { loss }\end{array}$ & Body & 8 & No & NA & Surgery & A (6) \\
\hline 24 & $\begin{array}{l}\text { Hirano et al, } \\
2011\end{array}$ & $66 / M$ & $\begin{array}{l}\text { Jaundice and } \\
\text { weight loss }\end{array}$ & Head & 3.5 & No & $\begin{array}{l}\text { Low bile duct } \\
\text { carcinoma }\end{array}$ & PD & $\mathrm{D}(12)$ \\
\hline 25 & $\begin{array}{l}\text { Araki et al, } \\
2011\end{array}$ & $68 / M$ & NO symptoms & Head & 2 & No & $\begin{array}{l}\text { Pancreatic } \\
\text { endocrine tumor } \\
\text { and right renal } \\
\text { cell carcinoma }\end{array}$ & PD & $A(52)$ \\
\hline 26 & $\begin{array}{l}\text { Lennerz et al, } \\
2011\end{array}$ & $71 / F$ & $\begin{array}{l}\text { Nausea and } \\
\text { vomiting }\end{array}$ & Body & 4.6 & Liver & $\begin{array}{l}\text { Pancreatic } \\
\text { endocrine } \\
\text { carcinoma (EUS- } \\
\text { FNA) }\end{array}$ & DP & A (8) \\
\hline 27 & $\begin{array}{l}\text { Anderson et } \\
\text { al, } 2016\end{array}$ & $54 / \mathrm{M}$ & $\begin{array}{l}\text { Abdominal } \\
\text { pain, jaundice }\end{array}$ & Head & 2.7 & LN & $\begin{array}{l}\text { Poorly } \\
\text { differentiated } \\
\text { adenocarcinoma } \\
\text { (EUS-FNA) }\end{array}$ & $\begin{array}{l}\text { PD } \\
\text { CRT }\end{array}$ & NA \\
\hline 28 & $\begin{array}{l}\text { Murata et al, } \\
2017\end{array}$ & $66 / M$ & $\begin{array}{l}\text { Obstructive } \\
\text { jaundice }\end{array}$ & Head & 3.0 & LN & $\begin{array}{l}\text { Pancreatic } \\
\text { carcinoma } \\
\text { (ERCP cytology) }\end{array}$ & $\begin{array}{l}\text { PD } \\
\text { Chemo }\end{array}$ & $\mathrm{D}(12)$ \\
\hline 29 & $\begin{array}{l}\text { Mori et al, } \\
2018\end{array}$ & $52 / M$ & Epigastric pain & Head & NA & No & $\begin{array}{l}\text { Adenocarcinoma } \\
\text { (ERCP cytology) }\end{array}$ & $\begin{array}{l}\text { Total } \\
\text { pancreatectomy }\end{array}$ & NA \\
\hline 30 & $\begin{array}{l}\text { Shimada et } \\
\text { al, } 2018\end{array}$ & $67 / F$ & Jaundice & Head & 1.8 & LN & $\begin{array}{l}\text { Adenocarcinoma } \\
\text { (ERCP biopsy) }\end{array}$ & PD & NA \\
\hline 31 & $\begin{array}{l}\text { Hirata et al, } \\
2019\end{array}$ & $64 / M$ & NA & Head & 3.3 & No & $\begin{array}{l}\text { Combined } \\
\text { carcinoma with } \\
\text { both ductal and } \\
\text { neuroendocrine } \\
\text { features (EUS- } \\
\text { FNA) }\end{array}$ & PD & NA \\
\hline Case 1 & & $38 / F$ & $\begin{array}{l}\text { Abdominal } \\
\text { pain }\end{array}$ & Head & 2.3 & $\begin{array}{l}\text { Liver; } \\
\text { LN }\end{array}$ & $\begin{array}{l}\text { Mixed ductal } \\
\text { and } \\
\text { neuroendocrine } \\
\text { neoplasms (EUS- } \\
\text { FNA) }\end{array}$ & $\begin{array}{l}\text { PD } \\
\text { Chemo }\end{array}$ & $\mathrm{D}(10)$ \\
\hline Case 2 & & $62 / F$ & $\begin{array}{l}\text { Abdominal } \\
\text { pain; vomit }\end{array}$ & Head & 2.5 & liver & $\begin{array}{l}\text { Mixed ductal- } \\
\text { neuroendocrine } \\
\text { tumor (EUS-FNA) }\end{array}$ & $\begin{array}{l}\text { Chemo; } \\
\text { Molecular- } \\
\text { targeted drug }\end{array}$ & $A(36)$ \\
\hline Case 3 & & $46 / M$ & $\begin{array}{l}\text { Abdominal } \\
\text { pain; weight } \\
\text { loss }\end{array}$ & Body & 3 & No & $\begin{array}{l}\text { Mixed ductal- } \\
\text { neuroendocrine } \\
\text { carcinoma (EUS- } \\
\text { FNA) }\end{array}$ & CRT & $A(60)$ \\
\hline
\end{tabular}




\section{Discussion}

Mixed ductal-neuroendocrine neoplasms of pancreas are defined as tumors composing of ductal adenocarcinomas and neuroendocrine neoplasms, with each part accounting for at least $30 \%$. To date, the final pathological diagnosis relies mainly on postoperative specimen. To our knowledge, this was the largest cohort worldwide of pancreatic mixed ductal - neuroendocrine neoplasms diagnosed by EUS-FNA specimen.

EUS-FNA is often the first-line diagnostic tool used in the evaluation of solid pancreatic masses with a reported sensitivity of $85 \%-95 \%$, specificity of $95 \%-98 \%$, and diagnostic accuracy of $78 \%-95 \%[38,39]$. In general, the cytomorphologic feature of adenocarcinomas and NENs is easy to distinguish, however, the accurate cytological diagnosis of mixed tumors is limited by a potential sampling bias and overlapping the cytological characteristics, that should be taken a particular caution [5, 40-42]. Immunohistochemical stain should be considered when encountering a tumor showing mixed morphological features, particularly when the two components are poorly differentiated [40,43]. The immunohistochemical markers of ductal differentiation include CK-7, CK-8, CK-18, CK-19, CA19-9, CEA, CA125, B72.3, MUC1 and MUC5AC, whereas neuroendocrine differentiation is identified by expression of synaptophysin, chromogranin A, CD56 and hormone production [2]. Tian et al. [44] reviewed 10 cases of pancreatic MiNENs in which an EUS-FNA and surgical treatment were performed, only $3(30 \%)$ were accurately diagnosed by biopsy. Similarly, Sullivan et al. [5] revealed that only 2 out of 9 patients (22.2\%) of mixed acinar-endocrine carcinoma were accurately diagnosed by EUS-FNA specimens before surgical resection. Of the previous reported cases of mixed ductal - neuroendocrine neoplasms, only 2 cases had two components observed in preoperative biopsy specimens $[21,33]$. Furthermore, FNA cytology or biopsy cannot determine whether each component accounts for at least $30 \%$, so it is difficult to make a definite diagnosis of MiNENs. When we encounter the tumor showing such mixed morphology features, we can diagnose combined tumor with mixed ductal and neuroendocrine features, suspicious of MiNENs.

Evidence based management strategies of pancreatic MiNENs have not been established because of the limit number of cases reported. Surgery is the treatment of choice in nearly all patients with localized MiNENs, which is also performed in approximately a quarter to one third of patients with advanced disease [45]. In unresectable cases, EUS-FNA is an important diagnostic tool to guide the clinical treatment. Some clinicians pointed out that treatment strategies for MiNENs should be based on the more dominant component (adenocarcinoma or NEC) [46, 47]. As most of the cases with a high grade neuroendocrine component, it is usually treated as pure NEC [47]. Kaji et al. [37] expressed that the NEC-targeted chemotherapy for MiNENs had been effective. EP (etoposide and cisplatin) therapy has been the most widely used in GEP NEC, which is typically followed by the treatment of the small-cell lung cancer[48]. Other drugs including oxaliplatin, temozolomide, and gemcitabine can also be assessed in mixed neuroendocrine with non-neuroendocrine component [49]. It has been reported that the molecular targeted drugs such as everolimus and sunitinib showing significantly prolonged progression - free survival among patients with advanced PanNETs [50]. In our cases, all of three patients targeted the predominant NENs component for treatment. Patients 2 and 3 achieved long-term survival with unresectable pancreatic tumor, which are far longer than the median overall survival of the current cohort. It suggests that our treatment strategy has been effective. hence, if the neuroendocrine component of these tumors was classified as NET G2, we propose appropriate adjuvant therapy rather than surgery.

The pathogenesis of MiNENs remains controversial and current molecular/genetic studies showed that the two components may have a common monoclonal origin [51-53]. In addition, the neuroendocrine components usually have a higher number of aberrations and a higher allele imbalance than non-neuroendocrine components, suggesting a more aggressive tumor biology [45]. The prognosis of MiNENs is not well known and the median overall survival (OS) ranging between 10.5 and 78 months [45]. Some scholars believed that the survival outcome of MiNENs was close to that of pure GEP-NEC, and it was more obvious in the advanced stage [54-56]. Similarly, Harada et al. [57] reported that the NEC component defined the prognosis, which was involved in most of the lymph node metastasis and vascular as well as perineural invasion in patients with MiNENs. In our study, the median OS of the reported cases of pancreatic mixed ductal - neuroendocrine neoplasms was 10 months, similar to that of panNEC [58].

In summary, we suggest that EUS-FNA is the most effective tool for diagnosis and subsequent guidance of therapy. It is difficult to diagnose mixed ductal-neuroendocrine neoplasms by EUS-FNA biopsy, however, it can identify mixed morphology and has high sensitivity. If the tumor grades of the neuroendocrine component were classified as NET G2 by EUS-FNA biopsy, we propose appropriate adjuvant therapy rather than surgery.

\section{Abbreviations}

CT; computed tomography; MRI:magnetic resonance imaging; EUS-FNA:Endoscopic ultrasound-guided fine needle aspiration; ERCP:Endoscopic retrograde cholangiopancreatography; H\&E:hematoxylin and eosin; HPFs:high-power fields; NENs:neuroendocrine neoplasms; NET:neuroendocrine tumor; NEC:neuroendocrine carcinoma; MANECs:mixed adenoneuroendocrine carcinomas; MiNENs:mixed neuroendocrine-non-neuroendocrine neoplasms; WHO, World Health Organization.

\section{Declarations}

\section{Acknowledgments}

Not applicable.

\section{Authors' contributions}


XYC conceived and designed the study. PYW and YW collected the clinical and follow-up information, performed the literature review and drafted the manuscript. JCC critically reviewed the manuscript. XXW, YJC and XW participated in the collection and follow-up data. YJ, JCC and XYC participated in the histological diagnosis and immunohistochemical evaluation. All authors read and approved the final manuscript.

\section{Funding}

Not applicable.

\section{Availability of data and materials}

Is available upon request from the corresponding author.

\section{Ethics approval and consent to participate}

This study was granted an exemption from requiring ethics approval from the Institutional Review Board of Peking Union Medical College Hospital.

\section{Consent to publication}

Written informed consent was obtained from the patients for the publication of this report and any accompanying images.

\section{Competing interests}

The authors declare that they have no competing interests.

\section{Author details}

1Department of Pathology, Peking Union Medical College Hospital, Chinese Academy of Medical Sciences and Peking Union Medical College, Tsinghua University, Beijing 100730, China

2 Department of Oncology, Peking Union Medical College Hospital, Chinese Academy of Medical Sciences and Peking Union Medical College, Tsinghua University, Beijing 100730, China

3 Department of Digestion, Peking Union Medical College Hospital, Chinese Academy of Medical Sciences and Peking Union Medical College, Tsinghua University, Beijing 100730, China

\section{References}

1. Kloppel G, Couvelard A, Hruban RH, Klimstra DS, Komminoth P, Osamura RY. Introduction. Neoplasms of the neuroendocrine pancreas. In: Lloyd RV, Osamura RY, Kloppel G, editors. WHO classification of Tumours of Endocrine Organs. Lyon: IARC; 2017. pp. 210-39.

2. klimstra DS, Klöppel G, La Rosa S, Rindi G. Classification of neuroendocrine neoplasms of the digestive system. In: Nagtegaal ID, Odze RD, Klimstra DS, editors. WHO classification of Tumours of Digestive System. Lyon: IARC; 2019. pp. 16-9.

3. Hashimoto Y, Murakami Y, Uemura K, Hayashidani Y, Sudo T, Ohge H, et al. Mixed ductal-endocrine carcinoma derived from intraductal papillary mucinous neoplasm (IPMN) of the pancreas identified by human telomerase reverse transcriptase (hTERT) expression. J Surg Oncol 2008;97(5):469-75.

4. Wang YH, Lin Y, Xue L, Wang JH, Chen MH, Chen J. Relationship between clinical characteristics and survival of gastroenteropancreatic neuroendocrine neoplasms: A single-institution analysis (1995-2012) in South China. BMC Endocr Disord. 2012;12:30.

5. Sullivan PS, Clebanoff JL, Hirschowitz SL. Hints to the diagnosis of mixed acinar-endocrine carcinoma on pancreatic fine-needle aspiration: avoiding a potential diagnostic pitfall. Acta cytologica. 2013;57(3):296-302.

6. Eusebi V, Capella C, Bondi A, Sessa F, Vezzadini P, Mancini AM. Endocrine-paracrine cells in pancreatic exocrine carcinomas. Histopathology. 1981;5(6):599-613.

7. Reid JD, Yuh SL, Petrelli M, Jaffe R. Ductuloinsular tumors of the pancreas: a light, electron microscopic and immunohistochemical study. Cancer. 1982;49(5):908-15.

8. Schron DS, Mendelsohn G. Pancreatic carcinoma with duct, endocrine, and acinar differentiation. A histologic, immunocytochemical, and ultrastructural study. Cancer. 1984;54(9):1766-70.

9. Ordonez NG, Balsaver AM, Mackay B. Mucinous islet cell (amphicrine) carcinoma of the pancreas associated with watery diarrhea and hypokalemia syndrome. Hum Pathol. 1988;19(12):1458-61.

10. Nonomura A, Mizukami Y, Matsubara F, Kono N, Nakanuma Y. Duct-islet cell tumor of the pancreas. A case report with immunohistochemical and electron microscopic findings. Acta pathologica japonica. 1989;39(5):328-35.

11. Kashiwabara K, Nakajima T, Shinkai H, Fukuda T, Oono Y, Kurabayashi Y, et al. A case of malignant duct-islet cell tumor of the pancreas immunohistochemical and cytofluorometric study. Acta pathologica japonica. 1991;41(8):636-41. 
12. Laine VJ, Ekfors TO, Gullichsen R, Nevalainen TJ. Immunohistochemical characterization of an amphicrine mucinous islet-cell carcinoma of the pancreas. Case report. APMIS: acta pathologica, microbiologica, et immunologica Scandinavica. 1992; 100(4): 335-340.

13. Nonomura A, Kono N, Mizukami Y, Nakanuma Y, Matsubara F. Duct-acinar-islet cell tumor of the pancreas. Ultrastruct Pathol. 1992;16(3):317-29.

14. Hassan MO, Gogate PA. Malignant mixed exocrine-endocrine tumor of the pancreas with unusual intracytoplasmic inclusions. Ultrastruct Pathol. 1993;17(5):483-93.

15. Okada Y, Mori H, Tsutsumi A. Duct-acinar-islet cell tumor of the pancreas. Pathol Int. 1995;45(9):669-76.

16. Morikane K, Kimura W, Inoue S, Muto T. A small glucagonoma of the pancreas with evident ductular and tubular structures. Journal of gastroenterology. 1997;32(4):562-5.

17. Terada T, Matsunaga Y, Maeta H, Endo K, Horie S, Ohta T. Mixed ductal-endocrine carcinoma of the pancreas presenting as gastrinoma with Zollinger-Ellison syndrome: an autopsy case with a 24-year survival period. Virchows Archiv: an international journal of pathology. 1999;435(6):606-11.

18. Leteurtre E, Brami F, Kerr-Conte J, Quandalle P, Lecomte-Houcke M. Mixed ductal-endocrine carcinoma of the pancreas: a possible pathogenic mechanism for arrhythmogenic right ventricular cardiomyopathy. Arch Pathol Lab Med. 2000;124(2):284-6.

19. Tanakaya K, Teramoto N, Konaga E, Takeuchi H, Yasui Y, Takeda A, et al. Mixed duct-acinar-islet cell tumor of the pancreas: report of a case. Surg Today. 2001;31(2):177-9.

20. Chatelain D, Parc Y, Christin-Maitre S, Parc R, Flejou JF. Mixed ductal-pancreatic polypeptide-cell carcinoma of the pancreas. Histopathology. 2002;41(2):122-6.

21. Terada T, Kawaguchi M, Furukawa K, Sekido Y, Osamura Y. Minute mixed ductal-endocrine carcinoma of the pancreas with predominant intraductal growth. Pathol Int. 2002;52(11):740-6.

22. Ballas KD, Rafailidis SF, Demertzidis C, Alatsakis MB, Pantzaki A, Sakadamis AK. Mixed exocrine-endocrine tumor of the pancreas. JOP: Journal of the pancreas. 2005;6(5):449-54.

23. Brandi G, Nobili E, Capizzi E, Corti B, Di Cicilia R, Di Marco M, et al. Exocrine-endocrine pancreatic cancer and alpha-fetoprotein. Pancreas. 2008;37(2):223-5.

24. Carter RR, Woodall CE, McNally ME, Talboy GE, Lankachandra KM, Van Way CW. Mixed ductal-endocrine carcinoma of the pancreas with synchronous papillary carcinoma-in-situ of the common bile duct: a case report and literature review-synchronous pancreatic and bile duct tumors. Am Surg. 2008;74(4):338-40.

25. Ahmad Z, Mumtaz S, Fatima S, Qureshi A. Mixed ductal-endocrine carcinoma of pancreas. BMJ Case Rep. $2011 ; 2011$.

26. Hirano H, Terada N, Yamada N, Yamanegi Y, Oyama H, Nishigami T, et al. A case of mixed ductal-endocrine carcinoma of the pancreas. Med Mol Morphol. 2011;44(1):58-62.

27. Araki K, Shimura T, Kobayashi T, Saito K, Wada W, Sasaki S, et al. Mixed ductal-endocrine carcinoma of the pancreas occurring as a double cancer: report of a case. International surgery. 2011;96(2):153-8.

28. Lennerz JK, Fernandez-Del Castillo C, Pitman MB. Mixed ductal-endocrine carcinoma of the pancreas metastatic to the liver. Pancreas. 2011;40(2):319-21.

29. Anderson MJ, Kwong CA, Atieh M, Pappas SG. Mixed acinar-neuroendocrine-ductal carcinoma of the pancreas: a tale of three lineages. BMJ Case Rep. 2016; 2016.

30. Murata M, Takahashi H, Yamada M, Song M, Hiratsuka M. A case of mixed adenoneuroendocrine carcinoma of the pancreas: Immunohistochemical analysis for histogenesis. Medicine. 2017;96(9):e6225.

31. Mori H, Hanada K, Minami T, Yano S, Fukuhara M, Maruyama $H$, et al. A case of mixed adenoneuroendocrine carcinoma of the pancreas mimicking intraductal papillary mucinous carcinoma. Clin J Gastroenterol. 2018;11(4):320-6.

32. Shimada N, Miwa S, Arai T, Kitagawa N, Akita S, linuma N, et al. Cystic mixed adenoneuroendocrine carcinoma of the pancreas: A case report. Int J Surg Case Rep. 2018;52:1-4.

33. Hirata K, Kuwatani M, Mitsuhashi T, Sugiura R, Kato S, Kawakubo K, et al. Mixed ductal-neuroendocrine carcinoma with unique intraductal growth in the main pancreatic duct. Endosc Ultrasound. 2019;8(2):129-30.

34. Kyriazi MA, Arkadopoulos N, Stafyla VK, Yiallourou Al, Dafnios N, Theodosopoulos T, et al. Mixed acinar-endocrine carcinoma of the pancreas: a case report and review of the literature. Cases J. 2009;2:6481.

35. Strait AM, Sharma N, Tsapakos MJ, Vaickus LJ, Liu X. Pancreatic mixed acinar-neuroendocrine carcinoma, a unique diagnostic challenge on FNA cytology: A small series of two cases with literature review. Diagn Cytopathol. 2018;46(11):971-6.

36. Kaji K, Seishima J, Yamato M, Miyazawa M, Komura T, Marukawa Y, et al. Clinical utility of endoscopic ultrasound-guided fine-needle aspiration in mixed adenoneuroendocrine carcinoma with signet-ring cells of the pancreas: a case report and review of the literature. Clin J Gastroenterol. 2016;9(1):43-8.

37. Kaji K, Seishima J, Yamato M, Miyazawa M, Komura T, Marukawa Y, et al. Clinical utility of endoscopic ultrasound-guided fine-needle aspiration in mixed adenoneuroendocrine carcinoma with signet-ring cells of the pancreas: a case report and review of the literature. Clin $\mathrm{J}$ Gastroenterol. 2016;9(1):43-8. 
38. Baek HW, Park MJ, Rhee YY, Lee KB, Kim MA, Park IA. Diagnostic accuracy of endoscopic ultrasound-guided fine needle aspiration cytology of pancreatic lesions. Journal of pathology translational medicine. 2015;49(1):52-60.

39. Alatawi A, Beuvon F, Grabar S, Leblanc S, Chaussade S, Terris B, et al. Comparison of $22 \mathrm{G}$ reverse-beveled versus standard needle for endoscopic ultrasound-guided sampling of solid pancreatic lesions. United European gastroenterology journal. 2015;3(4):343-52.

40. de Mestier L, Cros J, Neuzillet C, Hentic O, Egal A, Muller N, et al. Digestive System Mixed Neuroendocrine-Non-Neuroendocrine Neoplasms. Neuroendocrinology. 2017;105(4):412-25.

41. Levy MJ, Wiersema MJ. EUS-guided Trucut biopsy. Gastrointest Endosc. 2005;62(3):417-26.

42. Sina M, Cote GA, Korc M. Improving the diagnostic accuracy of endoscopic ultrasound-guided fine-needle aspiration using microRNAs. Gastroenterology. 2014;147(4):930-2.

43. Yoshioka S, Ebisu Y, Ishida M, Uemura Y, Yanagimoto H, Satoi S, et al. Cytological features of mixed adenoneuroendocrine carcinoma of the ampulla of Vater: A case report with immunocytochemical analyses. Diagn Cytopathol. 2018;46(6):540-6.

44. Tian F, Dai MH, Jia CW, Liu ZW, Li BL. Retrospective analysis of seven cases of pancreatic mixed adenoneuroendocrine carcinoma from a highvolume center and review of the literature. BMC Surg. 2019;19(1):89.

45. Frizziero M, Chakrabarty B, Nagy B, Lamarca A, Hubner RA, Valle JW, et al. Mixed Neuroendocrine Non-Neuroendocrine Neoplasms: A Systematic Review of a Controversial and Underestimated Diagnosis. J Clin Med. 2020; 9(1).

46. La Rosa S, Marando A, Sessa F, Capella C. Mixed Adenoneuroendocrine Carcinomas (MANECs) of the Gastrointestinal Tract: An Update. Cancers. 2012;4(1):11-30.

47. Garcia-Carbonero R, Sorbye H, Baudin E, Raymond E, Wiedenmann B, Niederle B, et al. ENETS Consensus Guidelines for High-Grade Gastroenteropancreatic Neuroendocrine Tumors and Neuroendocrine Carcinomas. Neuroendocrinology. 2016;103(2):186-94.

48. Terashima T, Morizane C, Hiraoka N, Tsuda H, Tamura T, Shimada Y, et al. Comparison of chemotherapeutic treatment outcomes of advanced extrapulmonary neuroendocrine carcinomas and advanced small-cell lung carcinoma. Neuroendocrinology. 2012;96(4):324-32.

49. Fazio N, Spada F, Giovannini M. Chemotherapy in gastroenteropancreatic (GEP) neuroendocrine carcinomas (NEC): a critical view. Cancer Treat Rev. 2013;39(3):270-4.

50. Ishida H, Lam AK. Pancreatic neuroendocrine neoplasms: The latest surgical and medical treatment strategies based on the current World Health Organization classification. Crit Rev Oncol Hematol. 2020;145:102835.

51. Jesinghaus M, Konukiewitz B, Keller G, Kloor M, Steiger K, Reiche M, et al. Colorectal mixed adenoneuroendocrine carcinomas and neuroendocrine carcinomas are genetically closely related to colorectal adenocarcinomas. Mod Pathol. 2017;30(4):610-9.

52. Woischke C, Schaaf CW, Yang HM, Vieth M, Veits L, Geddert H, et al. In-depth mutational analyses of colorectal neuroendocrine carcinomas with adenoma or adenocarcinoma components. Mod Pathol. 2017;30(1):95-103.

53. Farooq F, Zarrabi K, Sweeney K, Kim J, Bandovic J, Patel C, et al. Multiregion Comprehensive Genomic Profiling of a Gastric Mixed Neuroendocrine-Nonneuroendocrine Neoplasm with Trilineage Differentiation. J Gastric Cancer. 2018;18(2):200-7.

54. Sorbye H, Strosberg J, Baudin E, Klimstra DS, Yao JC. Gastroenteropancreatic high-grade neuroendocrine carcinoma. Cancer. 2014;120(18):2814-23.

55. Sorbye H, Welin S, Langer SW, Vestermark LW, Holt N, Osterlund P, et al. Predictive and prognostic factors for treatment and survival in 305 patients with advanced gastrointestinal neuroendocrine carcinoma (WHO G3): the NORDIC NEC study. Ann Oncol. 2013;24(1):152-60.

56. Walter T, Tougeron D, Baudin E, Le Malicot K, Lecomte T, Malka D, et al. Poorly differentiated gastro-entero-pancreatic neuroendocrine carcinomas: Are they really heterogeneous? Insights from the FFCD-GTE national cohort. Eur J Cancer. 2017;79:158-65.

57. Harada K, Sato Y, Ikeda H, Maylee H, Igarashi S, Okamura A, et al. Clinicopathologic study of mixed adenoneuroendocrine carcinomas of hepatobiliary organs. Virchows Archiv: an international journal of pathology. 2012;460(3):281-9.

58. Yan J, Yu S, Jia C, Li M, Chen J. Molecular subtyping in pancreatic neuroendocrine neoplasms: New insights into clinical, pathological unmet needs and challenges. Biochimica et biophysica acta Reviews on cancer. 2020;1874(1):188367.

\section{Figures}



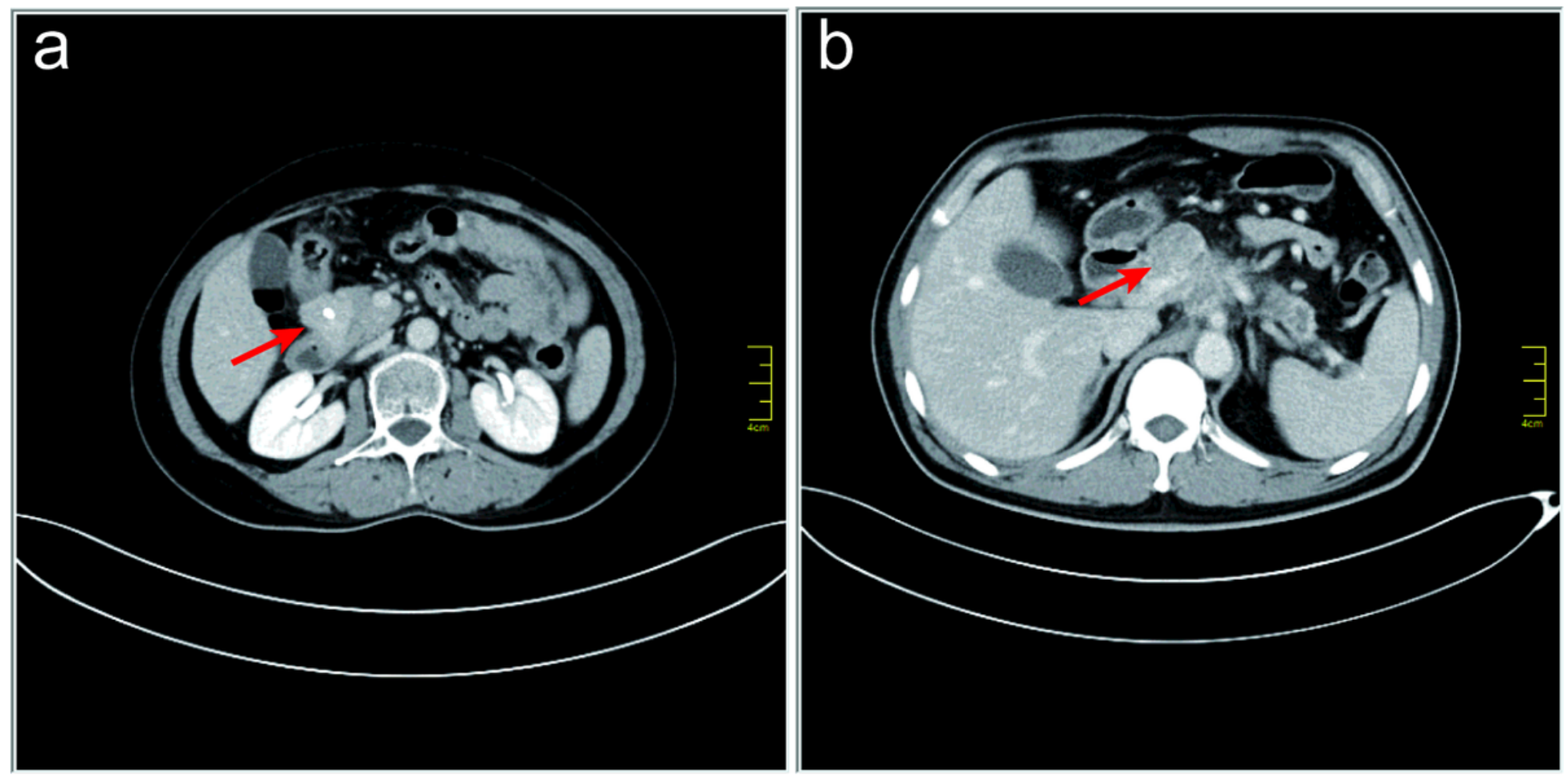

\section{Figure 1}

Contrast enhanced CT of the abdomen (cases 2 and 3). a The images demonstrating a solid $2.5 \mathrm{~cm}$ mass (arrow) in the head of the pancreas with foci of calcification (case 2). b The images showing a solid mass (arrow) located at the neck of the pancreas measuring $3 \mathrm{~cm}$ in diameter (case 3 ). 


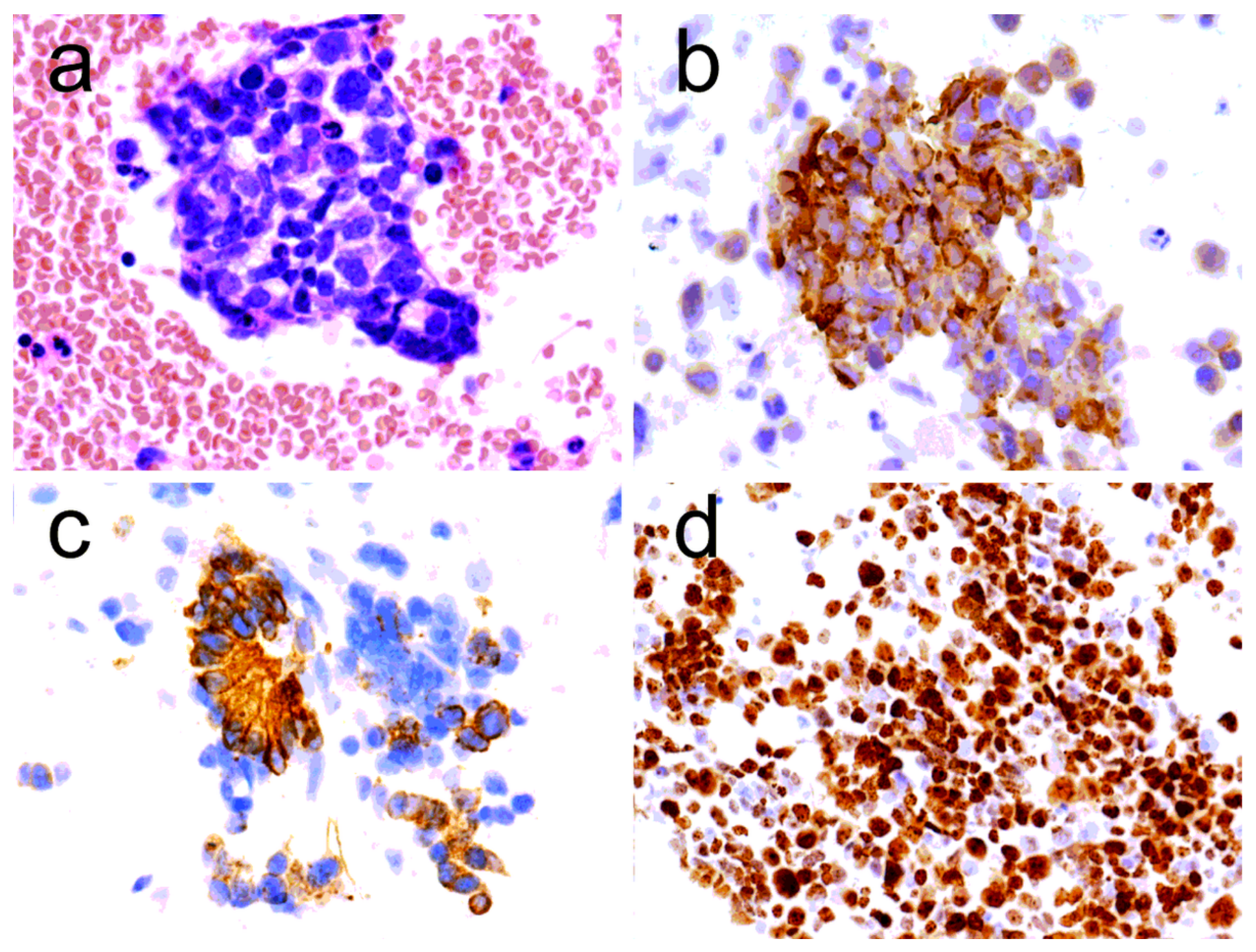

Figure 2

EUS-FNA cytology (HE stain) and immunocytochemistry (b-d) of case 1 a Pancreas FNA smear showing cell clusters and dispersed single cells with round to oval nuclei, a 'salt - and - pepper' chromatin, conspicuous nucleoli, and moderate finely granular cytoplasm. $x$ 200. $b$ Chromogranin $A, x$ 200. c Cytokeratin, x200. d Ki-67, x100. 


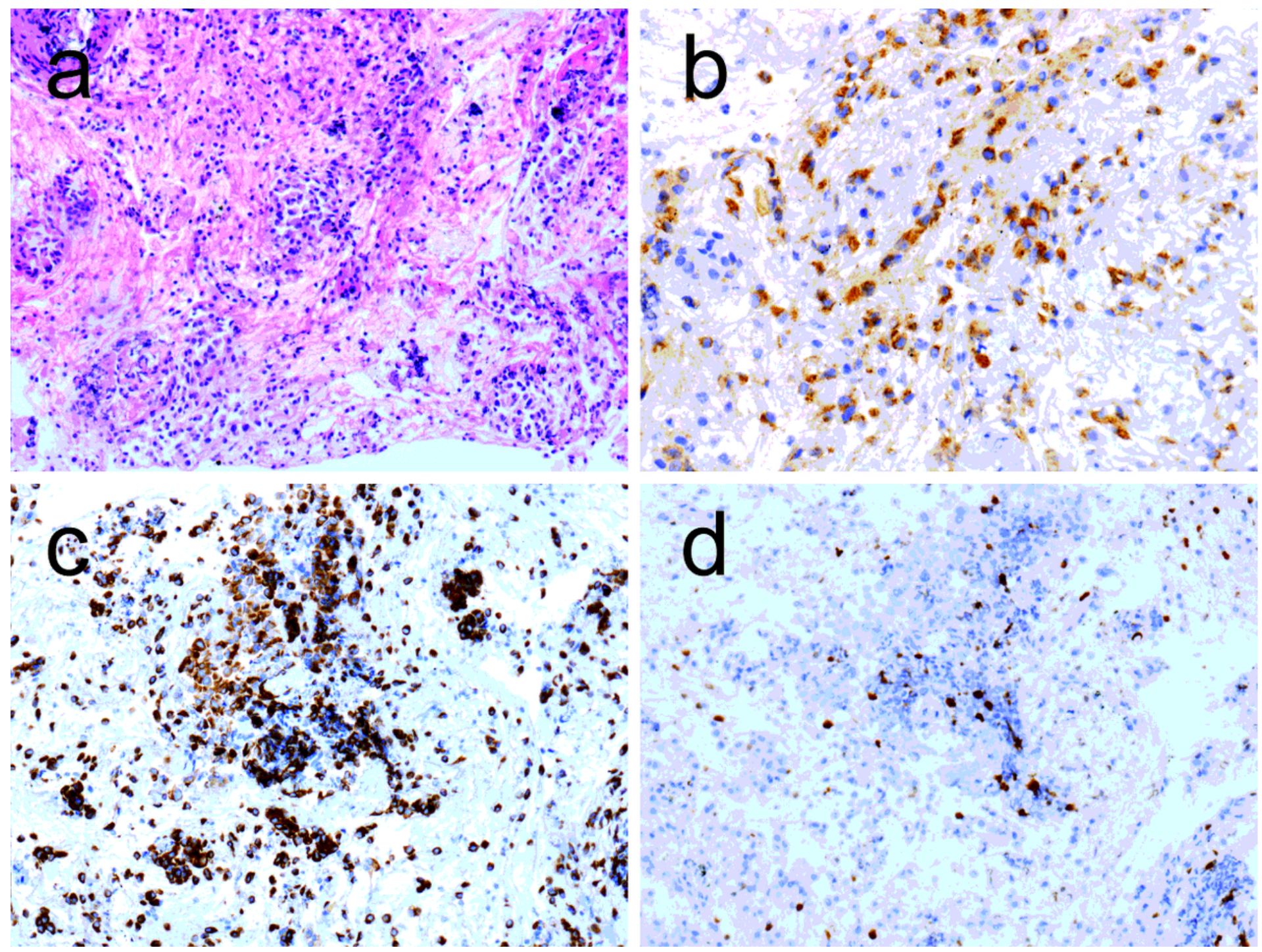

Figure 3

EUS-FNA cytology (HE stain) and immunocytochemistry (b-d) of case 2 a There were two components in the smear, including glandular structure and scattered plasmacytoid cells, x 60. b Chromogranin A, x 100. c Cytokeratin, x 100. d Ki-67, x100. 

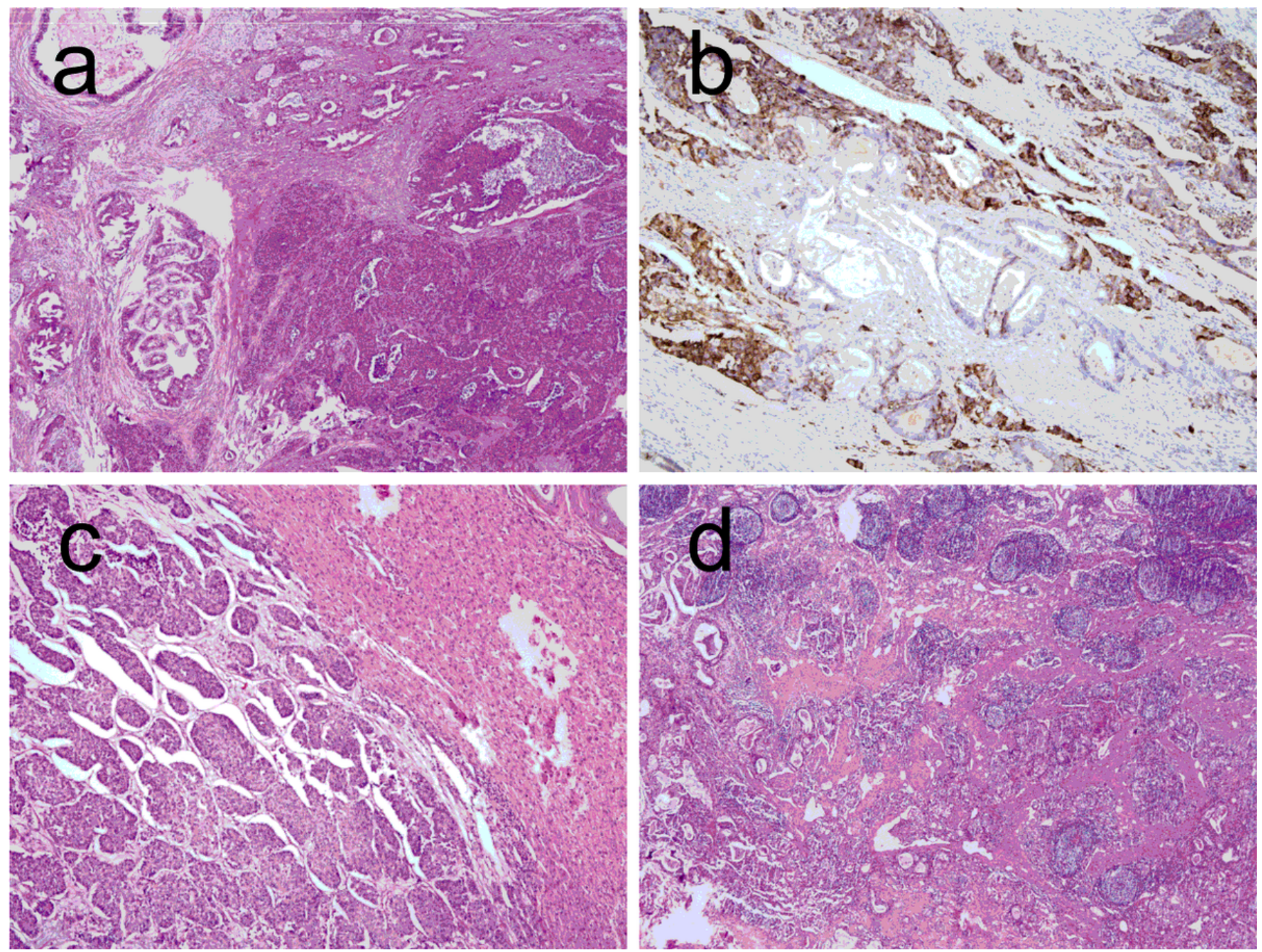

\section{Figure 4}

Histological features (HE stain) and immunohistochemistry of postoperative specimen (case 1). a The moderate differentiated mucinous carcinoma and a poorly differentiated neuroendocrine carcinoma intermingling together. b The neuroendocrine cells were positive for chromogranin A. $c$ 2/4 involved lymph nodes were infiltrated by a mixture of adenocarcinoma and neuroendocrine carcinoma. $d$ Metastasis of the neuroendocrine carcinoma was found in the liver. 